\title{
Response of three shrub communities in southeastern Idaho to spring-applied tebuthiuron
}

\author{
ROBERT B. MURRAY
}

Tebuthiuron ${ }^{1}$ has effectively controlled a variety of woody species in the southcentral United States (Scifres et al. 1979, Bovey et al. 1981) and big sagebrush (Britton and Sneva 1981, 1983; Whitson and Alley 1984; Clary et al. 1985; and McDaniel and Balliette 1986) in the western United States. Scifres and Mutz (1978) reported increased grass standing crops at 1,2 , and 3 years following application of tebuthiuron at $2.24 \mathrm{~kg} \mathrm{ha}^{-1}$ to mixed brush stands in Texas. Forb production declined initially where tebuthiuron was applied at rates greater than $1.0 \mathrm{~kg} \mathrm{ha}^{-1}$, but production returned to normal 3 years after application rates as high as $4.48 \mathrm{~kg}$ $\mathrm{ha}^{-1}$. Sosebee et al. (1979) found grass production was greatly reduced for 3 growing seasons and forb production for 1 season following application of tebuthiuron in May to broom snakeweed (Xanthocephalum sarothrae Skinner) stands in Texas. Tebuthiuron effectively controlled big sagebrush when applied at rates greater than $2.0 \mathrm{~kg} \mathrm{ha}^{-1}$ in central Orgeon (Britton and Sneva 1981). Herbage yields declined when the rate of application of tebuthiuron to big sagebrush was increased from 0.25 to $2.0 \mathrm{~kg}$ $\mathrm{ha}^{-1}$; fall applications were more detrimental than spring applications (Britton and Senva 1983). This finding appears to contradict that found by Sosebee et al. (1979) for species in Texas. Whitson and Alley (1984), in Wyoming, reported big sagebrush was controlled by tebuthiuron at rates as low as $0.6 \mathrm{~kg} \mathrm{ha}^{-1}$. Live canopy covers of western wheatgrass [Pascopyrum smithii (Rydb.) $A$. Löve], prairie junegrass [Koeleria pyrimidata (Cam.) Beauv.], needle-and-thread grass (Stipa comata Trin. and Rupr.), and green needlegrass (Stipa viridula Trin.) were not affected by tebuthiuron at rates as great as $1.1 \mathrm{~kg} \mathrm{ha}^{-1}$, but the first year after application these cool-season grasses were chlorotic in appearance (Whitson and Alley 1984). In Utah, Clary et al. (1985) found application of tebuthiuron to sagebrush range at rates of $0.6 \mathrm{~kg} \mathrm{ha}^{-1}$ and higher resulted in decreased production of most shrub species, and at rates of $1.3 \mathrm{~kg} \mathrm{ha}^{-1}$ and higher the herbaceous composition changed from mostly perennial to more annuals.

ITebuthiuron is a product developed by Eli Lilly and Company, Indianapolis, Indiana. Mention of the pesticides or proprietary products does not constitute an endorsement or recommendation for use by the USDA nor imply registration under FIFRA as amended.

Author is range scientist, (now retired) USDA-ARS, located at the U.S. Sheep Experiment Station, Dubois, Idaho 83423 . This research was partially supported by a grant to the University of Idaho, cooperators with the USDA-Agricultural Research Service, from Lilly Research Labs, Greenfield, Ind.

Acknowled gement is given to Dr. Gary Richardson, statistician, USDA-ARS, Fort Collins, Colo., for developing the statistical procedures.

Manuscript accepted 27 May 1987.

Table 1. Live shrub canopy cover percentage (mean and \pm standard error) before (1979) and one year after (1980) tebuthiuron application at the mountain big angebruah aite on the U.S. Sheep Experiment Station.

\begin{tabular}{|c|c|c|c|c|c|c|}
\hline \multirow[b]{2}{*}{ Shrub } & \multirow[b]{2}{*}{ Year } & \multicolumn{5}{|c|}{ Tebuthiuron Application Rate and Formulation ( $\mathrm{kg} \mathrm{ha}^{-1}$ active ingredient and percent) } \\
\hline & & Untreated & $0.6(20 \mathrm{P})$ & $0.6(40 \mathrm{P})$ & $1.1(20 \mathrm{P})$ & $1.1(40 \mathrm{P})$ \\
\hline $\begin{array}{c}\text { Mountain big } \\
\text { Sagebrush }\end{array}$ & $\begin{array}{l}1979 \\
1980 \\
\text { Diff. }\end{array}$ & $\begin{array}{c}28.5 \pm 1.6 \\
26.1 \pm 1.6 \\
-2.4\end{array}$ & $\begin{array}{c}29.4 \pm 1.8 \\
8.8 \pm 2.3 \\
-20.6\end{array}$ & $\begin{array}{c}23.9 \pm 1.7 \\
12.9 \pm 2.3 \\
-11.0\end{array}$ & $\begin{array}{c}26.4 \pm 1.5 \\
3.5 \pm 1.1 \\
-22.9\end{array}$ & $\begin{array}{c}26.2 \pm 2.4 \\
7.0 \pm 1.2 \\
-19.2\end{array}$ \\
\hline $\begin{array}{l}\text { Antelope } \\
\text { Bitterbrush }\end{array}$ & $\begin{array}{l}1979 \\
1980 \\
\text { Diff. }\end{array}$ & $\begin{array}{c}1.2 \pm 0.6 \\
2.3 \pm 0.8 \\
1.1\end{array}$ & $\begin{array}{c}1.0 \pm 0.5 \\
1.3 \pm 0.6 \\
0.3\end{array}$ & $\begin{array}{c}3.8 \pm 1.4 \\
1.1 \pm 0.6 \\
-2.7\end{array}$ & $\begin{array}{c}1.6 \pm 0.6 \\
1.1 \pm 0.4 \\
-0.6\end{array}$ & $\begin{array}{c}1.4 \pm 0.6 \\
0.2 \pm 0.1 \\
-1.2\end{array}$ \\
\hline $\begin{array}{l}\text { Gray } \\
\text { Horsebrush }\end{array}$ & $\begin{array}{l}1979 \\
1980 \\
\text { Diff. }\end{array}$ & $\begin{array}{c}0.6 \pm 0.3 \\
0.4 \pm 0.1 \\
-0.2\end{array}$ & $\begin{array}{c}0.5 \pm 0.1 \\
0.4 \pm 0.2 \\
-0.1\end{array}$ & $\begin{array}{c}0.4 \pm 0.1 \\
0.8 \pm 0.4 \\
0.4\end{array}$ & $\begin{array}{c}0.4 \pm 0.1 \\
0.3 \pm 0.1 \\
-0.1\end{array}$ & $\begin{array}{c}0.5 \pm 0.2 \\
0.2 \pm 0.1 \\
-0.3\end{array}$ \\
\hline Total shrubs & $\begin{array}{l}1979 \\
1980 \\
\text { Diff. }\end{array}$ & $\begin{array}{c}30.4 \\
28.9 \\
-1.5\end{array}$ & $\begin{array}{c}30.9 \\
10.4 \\
-20.5\end{array}$ & $\begin{array}{c}28.2 \\
14.8 \\
-13.4\end{array}$ & $\begin{array}{r}28.4 \\
4.9 \\
-23.5\end{array}$ & $\begin{array}{r}28.1 \\
7.4 \\
-20.7\end{array}$ \\
\hline
\end{tabular}


The objective of this study was to determine the effect of tebuthiuron applied during the spring at 0.6 and $1.1 \mathrm{~kg} \mathrm{ha}^{-1}$ as 20 and $40 \%$ active ingredient pellets on plant species occurring on sites dominated by mountain big sagebrush (Artemisia tridentata subsp. vaseyana Nutt.), threetip sagebrush ( $A$. tripartita $\mathrm{Rydb}$.), and gray horsebrush (Tetradymia canescens DC). The 2 sagebrush species form distinctive communities in southeastern Idaho, while gray horsebrush is a component of both communities and often dominates after burning. Gray horsebrush is a species poisonous to sheep and may result in "big head"-a fatal disorder.

\section{Study Area and Methods}

The study was conducted on the U.S. Sheep Experiment Station located about $8 \mathrm{~km}$ north of Dubois on the Upper Snake River Plain. Sites were chosen where mountain big sagebrush, threetip sagebrush, and gray horsebrush were the dominant shrubs, respectively. Nomenclature for plant species follows that of Hitchcock et al. (1977) except for certain proposed changes in grass names by Dewey (1983) and Barkworth et al. (1983).

The mountain big sagebrush site is a mountain big sagebrushthickspike wheatgrass [Elymus lanceolatus (Scribn. and Smith)

Table 2a. Density of shrubs ( \pm standard error) at the mountain big sagebrush, threetip sagebrush, and gray horsebrush sites in relation to tebuthiuron rates and formulations in 1984.

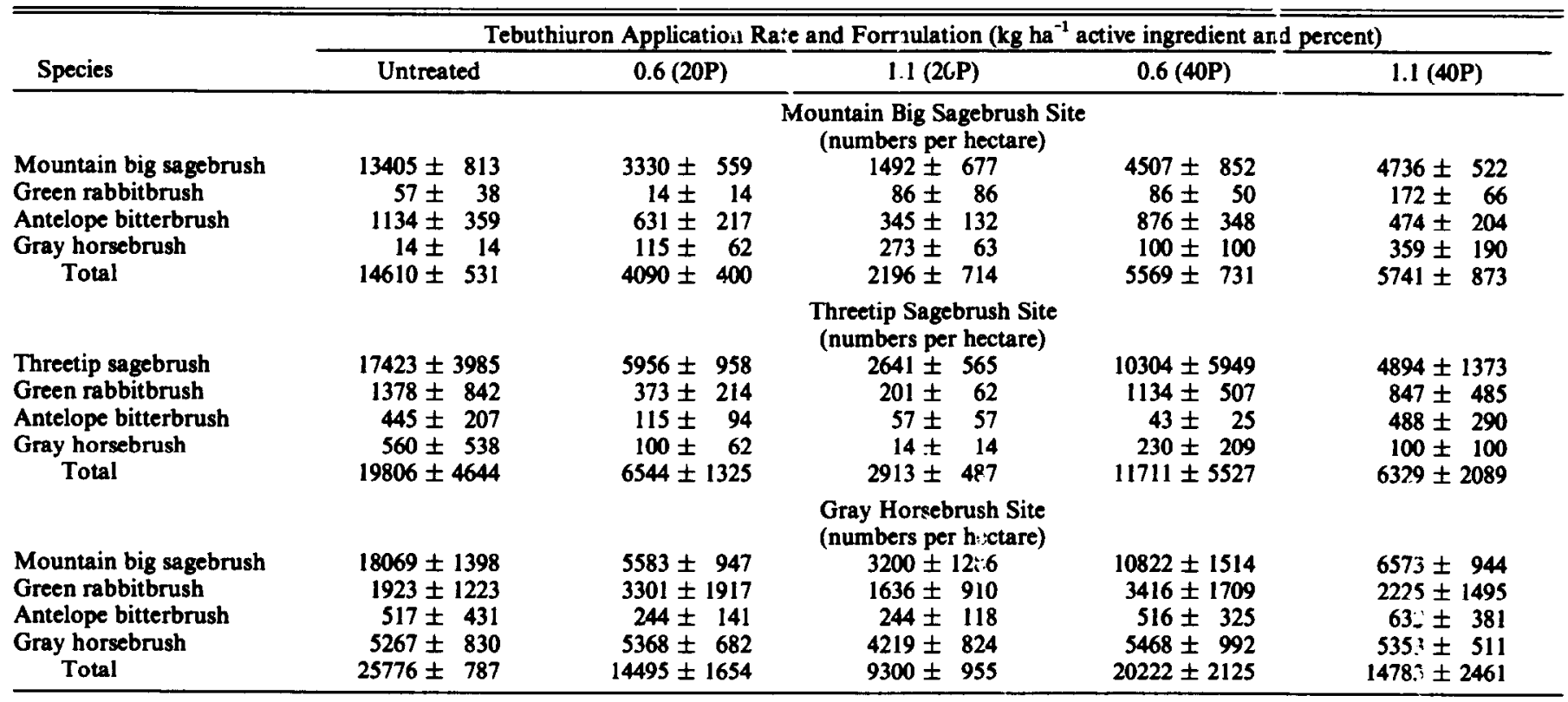

Table 2b. Density of shrubs ( \pm standard error) at the mountain big sagebrush, threetip sagebrush, and gray horsebrush sites in relation to tebuthiuron rates and formulates in 1984.

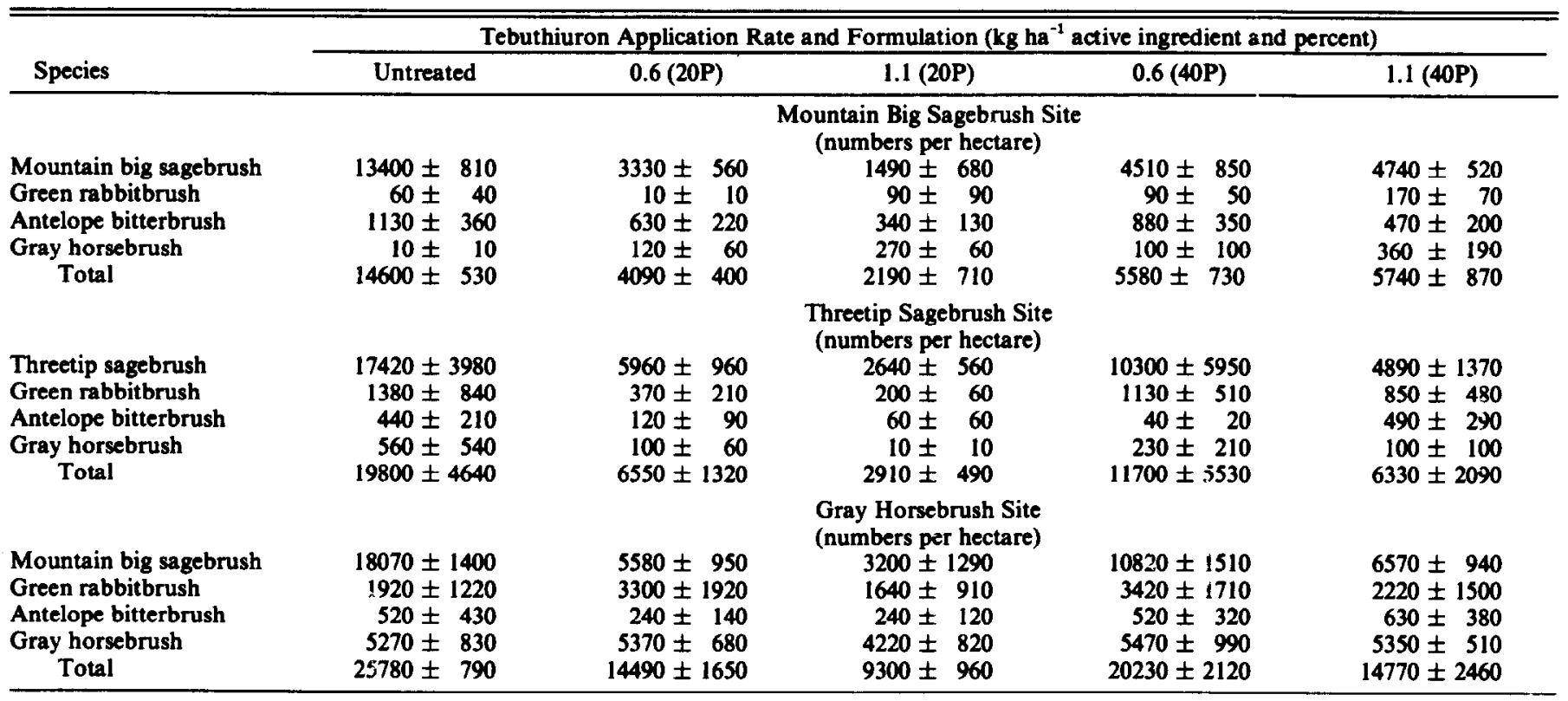


Gould] (Dewey 1983) vegetation type. Associated species include green rabbitbrush [(Chrysothamnus viscidiflorus (Hook.) Nutt.], gray horsebrush, antelope bitterbrush [Purshia tridentata (Pursh.) DC], bluegrasses (Poa spp.), lupines (Lupinus spp.), and pussytoes (Antennaria rosea Greene). Soils were in the tentative Laird series, a Pachic Argiustol. The A horizon was a dark grayish brown, noncalcareous silt loam about $15 \mathrm{~cm}$ thick. The $B$ horizon was dark grayish brown to grayish brown, noncalcareous clay loam that extends to about $76 \mathrm{~cm}$ deep. The $\mathrm{C}$ horizon was a pale brown, calcareous loam. Basalt bedrock began below $100 \mathrm{~cm}$.

The threetip sagebrush site is a threetip sagebrush-bluebunch wheatgrass [Pseduoroegneria spicata (Pursh.) A. Löve] (Barkworth et al. 1983) habitat type with green rabbitbrush, antelope bitterbrush, prickly gilia [Leptodactylon pungens (Torr.) Rydb.] principal shrub associates. Other species include Sandberg's bluegrass (Poa sandbergi Vasey), pussytoes (Antennaria Gaertn spp.), locoweeds (Astragalus L. spp.), and longleaf phlox (Phlox longifolia Nutt.). Soils belong to the tentative Eagle Cone series, a Typic Calcixeroll. The surface horizon was grayish brown, slightly calcareous, very stony loam about $25 \mathrm{~cm}$ thick. The $\mathrm{C}$ horizion was light gray to light brownish gray, strongly calcareous, very stony loam that extended to a depth of 50 to $100 \mathrm{~cm}$. It was underlain by shattered, lime coated basaltic bedrock. Rock reached the surface on about 20 to $30 \%$ of the area.

The gray horsebrush site was an area formerly dominated by mountain big sagebrush that was burned by a wildfire in August 1974. Gray horsebrush and green rabbitbrush sprouted vigorously from dormant buds on basal stems following burning. Shrubs were generally less than $40 \mathrm{~cm}$ tall. The habitat type and soil were similar to that of the mountain big sagebrush site.

Records obtained from the official National Weather Station located near the Station headquarters indicated annual precipitation in 1979, the year of herbicide application, was $20 \%$ below the 55-year average of $288 \mathrm{~mm}$. In subsequent years of study (1980-1983) annual precipitation was $28,22,43$, and $82 \%$ greater than the long-term average, respectively.

Fifteen 15.2- by $15.2-\mathrm{m}$ plots were arranged in a completely randomized design at the mountain big sagebrush and threetip sagebrush sites. The experiment in the gray horsebrush site was arranged in a randomized complete block design with each of the 3 blocks located at a separate loation. Treatments consisted of an untreated control and 2 rates $\left(0.6\right.$ and $\left.1.1 \mathrm{~kg} \mathrm{ha}^{-1}\right)$ of each of the 2 formulations [20 (20P) and 40\% (40P) pellets] of tebuthiuron. Treatments were replicated 3 times. Herbicide pellets were mixed

Table 3. Production (kg ha-1 oven-dry weight) by plant group for mountain big sagebrush tebuthiuron treatment site at the U.S. Sheep Experiment Station.

\begin{tabular}{|c|c|c|c|c|c|c|}
\hline \multirow[b]{2}{*}{ Plant Group } & \multirow[b]{2}{*}{ Year } & \multicolumn{5}{|c|}{ Tebuthiuron Application Rate and Formulation ( $\mathrm{kg} \mathrm{ha}^{-1}$ active ingredient and percent) } \\
\hline & & Untreated & $0.6(20 \mathrm{P})$ & $0.6(40 \mathrm{P})$ & $1.1(20 \mathrm{P})$ & $1.1(40 \mathrm{P})$ \\
\hline Mountain big sagebrush & $\begin{array}{l}1981 \\
1982 \\
1983\end{array}$ & $\begin{array}{l}486^{a 1} \\
462^{*} \\
677^{a}\end{array}$ & $\begin{array}{l}55^{\mathrm{b}} \\
79^{\mathrm{b}} \\
32^{\mathrm{b}}\end{array}$ & $\begin{array}{r}60^{\mathrm{b}} \\
83^{\mathrm{b}} \\
115^{\mathrm{b}}\end{array}$ & $\begin{array}{c}9^{\mathrm{b}} \\
11^{\mathrm{b}} \\
88^{\mathrm{b}}\end{array}$ & $\begin{array}{l}96^{\mathrm{b}} \\
73^{\mathrm{b}} \\
51^{\mathrm{b}}\end{array}$ \\
\hline Shrubs & $\begin{array}{l}1981 \\
1982 \\
1983\end{array}$ & $\begin{array}{l}617^{\circ} \\
546^{\circ} \\
816^{\circ}\end{array}$ & $\begin{array}{l}99^{b} \\
87^{c} \\
93^{b c}\end{array}$ & $\begin{array}{l}141^{b} \\
151^{b} \\
174^{c}\end{array}$ & $\begin{array}{c}22^{\mathrm{b}} \\
41^{\mathrm{c}} \\
100^{\mathrm{bc}}\end{array}$ & $\begin{array}{r}149^{\mathrm{c}} \\
97^{\mathrm{c}} \\
80^{\mathrm{b}}\end{array}$ \\
\hline Grasses & $\begin{array}{l}1981 \\
1982 \\
1983\end{array}$ & $\begin{array}{l}325^{\circ} \\
147^{\circ} \\
270^{\circ}\end{array}$ & $\begin{array}{l}444^{\mathrm{a}} \\
257^{\mathrm{a}} \\
589^{\mathrm{b}}\end{array}$ & $\begin{array}{l}555^{a} \\
239^{a} \\
517^{a b}\end{array}$ & $\begin{array}{l}384^{\circ} \\
160^{\circ} \\
540^{\mathrm{b}}\end{array}$ & $\begin{array}{l}605^{b} \\
331^{\mathrm{a}} \\
567^{\mathrm{b}}\end{array}$ \\
\hline Forbs & $\begin{array}{l}1981 \\
1982 \\
1983\end{array}$ & $\begin{array}{l}400^{n} \\
231^{\prime \prime} \\
528^{\circ}\end{array}$ & $\begin{array}{l}281^{\star} \\
271^{*} \\
507^{\circ}\end{array}$ & $\begin{array}{l}331^{*} \\
334^{*} \\
621^{*}\end{array}$ & $\begin{array}{l}236^{\prime} \\
385^{n} \\
590^{*}\end{array}$ & $\begin{array}{l}339^{*} \\
393^{*} \\
656^{*}\end{array}$ \\
\hline
\end{tabular}

${ }^{1}$ Values not followed by the same letter in the same row are significantly different at $P \leq .05$.

Table 4. Live shrub canopy cover percentage (mean and \pm standard error) before (1979) and one year after (1980) tebuthiuron application at the threetip sagebrush site on the U.S. Sheep Experiment Station.

\begin{tabular}{|c|c|c|c|c|c|c|}
\hline \multirow[b]{2}{*}{ Shrub } & \multirow[b]{2}{*}{ Year } & \multicolumn{5}{|c|}{ Tebuthiuron Application Rate and Formulation ( $\mathrm{kg} \mathrm{ha}^{-1}$ active ingredient and percent) } \\
\hline & & Untreated & $0.6(20 \mathrm{P})$ & $0.6(40 \mathrm{P})$ & $1.1(20 \mathrm{P})$ & $1.1(40 \mathrm{P})$ \\
\hline & \multicolumn{6}{|c|}{ Percent } \\
\hline Threetip sagebrush & $\begin{array}{l}1979 \\
1980 \\
\text { Diff. }\end{array}$ & $\begin{array}{c}22.2 \pm 2.2 \\
21.9 \pm 2.9 \\
\quad-0.3\end{array}$ & $\begin{array}{c}20.4 \pm 2.5 \\
8.5 \pm 1.9 \\
-11.9\end{array}$ & $\begin{array}{c}23.1 \pm 1.5 \\
10.1 \pm 1.3 \\
-12.4\end{array}$ & $\begin{array}{c}18.0 \pm 1.6 \\
4.2 \pm 0.8 \\
-13.8\end{array}$ & $\begin{array}{c}20.2 \pm 1.8 \\
6.0 \pm 0.7 \\
-14.2\end{array}$ \\
\hline Green rabbitbrush & $\begin{array}{l}1979 \\
1980 \\
\text { Diff. }\end{array}$ & $\begin{array}{c}0.6 \pm 0.1 \\
0.6 \pm 0.2 \\
0\end{array}$ & $\begin{array}{c}0.2 \pm 0.1 \\
1.1 \pm 0.4 \\
0.9\end{array}$ & $\begin{array}{c}0.8 \pm 0.2 \\
1.0 \pm 0.2 \\
0.2\end{array}$ & $\begin{array}{c}0.5 \pm 0.2 \\
1.1 \pm 0.4 \\
0.6\end{array}$ & $\begin{array}{c}0.5 \pm 0.2 \\
0.6 \pm 0.2 \\
0.1\end{array}$ \\
\hline Antelope bitterbrush & $\begin{array}{l}1979 \\
1980 \\
\text { Diff. }\end{array}$ & $\begin{array}{c}0.4 \pm 0.2 \\
0.8 \pm 0.4 \\
0.4\end{array}$ & $\begin{array}{c}0.2 \pm 0.2 \\
\mathrm{~T}^{*} \\
-0.2\end{array}$ & $\begin{array}{l}0 \\
0 \\
0\end{array}$ & $\begin{array}{c}1.8 \pm 0.8 \\
0.7 \pm 0.4 \\
-1.1\end{array}$ & $\begin{array}{l}1.2 \pm 0.5 \\
0.2 \pm 0.1 \\
-1.0\end{array}$ \\
\hline Gray horsebrush & $\begin{array}{l}1979 \\
1980 \\
\text { Diff. }\end{array}$ & $\begin{array}{c}0.1 \pm 0.1 \\
0.1 \pm 0.1 \\
0\end{array}$ & $\begin{array}{l}\text { T } \\
0 \\
0\end{array}$ & $\begin{array}{c}\mathrm{T} \\
0.2 \pm 0.1 \\
0.2\end{array}$ & $\begin{array}{c}0.1 \pm 0.1 \\
0.1 \pm 0.1 \\
0\end{array}$ & $\begin{array}{l}0.2 \pm 0.1 \\
0.2 \pm 0.1 \\
\quad 0\end{array}$ \\
\hline Total shrubs & $\begin{array}{l}1979 \\
1980 \\
\text { Diff. }\end{array}$ & $\begin{array}{r}23.3 \\
23.4 \\
0.1\end{array}$ & $\begin{array}{r}20.9 \\
9.6 \\
-11.3\end{array}$ & $\begin{array}{r}23.9 \\
11.9 \\
-12.0\end{array}$ & $\begin{array}{r}20.3 \\
6.1 \\
-14.2\end{array}$ & $\begin{array}{r}22.1 \\
6.9 \\
-15.2\end{array}$ \\
\hline
\end{tabular}

-Trace less than or equal to $0.05 \%$. 
with blank pellets to obtain sufficient bulk for easy hand distribution. These mixtures were applied by hand 7 May 1979 at the threetip sagebrush site and 31 May 1979 at the mountain big sagebrush and gray horsebrush sites.

Estimates of live crown cover of shrubs were made during June 1979 and 1980 . Four lines were randomly located across each plot and canopy cover of each shrub species estimated in twenty-five 20-by $50 \mathrm{~cm}$ quadrats per line using the method outlined by Daubenmire (1959). The 1979 estimates represented the pretreatment cover, while the 1980 estimates represent effects on shrubs 1 year following treatment. The density of live shrubs, except seedlings less than $5 \mathrm{~cm}$ tall, was determined in August 1984 by counting all individuals of each species in each 15.2- by 15.2-m plot.

During mid-June 1981, 1982, and 1983, after the majority of the grasses and forbs reached maximum growth, five $0.45-\mathrm{m}^{2}$ circular plots were randomly placed in each plot to obtain live standing crop data for individual grass, forb, and shrub species. Subplots were randomly placed each year. In 1981 the individual major herbaceous species were harvested at $1-\mathrm{cm}$ stubble height, ovendried at $70^{\circ} \mathrm{C}$, and weighed. Weights of minor species were estimated by the technique described by Pechanec and Pickford (1937). During subsequent years all species were clipped, ovendried, and weighed. Plots at the gray horsebrush site were clipped only in 1981 and 1982. Only current growth of shrubs was harvested.

Analyses of variance were used to determine treatment effects on individual species and plant yield categories. Where individual species occurred in all treatment, year, and replication combinations, they were analyzed separately. Additional analyses included all shrub, all grass, and all forb categories. Dunnett's procedure (Dunnett 1964) was used to test significance of herbicide treatments from untreated vegetation means at $P \leq .05$.

\section{Results and Discussion}

Leaves of mountain big sagebrush and threetip sagebrush exhibited herbicidal symptoms (chlorosis and withering) by late August 1979. Although most leaves appeared unhealthy, they were retained over winter, and were gradually dropped during the spring of 1980 . By early summr most dead leaves were shed. In contrast, gray sagebrush and antelope bitterbrush exhibited only minimal herbicide symptoms by the end of summer 1980 . The most marked effect, evident by spring 1981 , on the gray horsebrush site was the relatively large patches ( $30-60 \mathrm{~cm}$ diameter) devoid of any living vegetation in plots treated with tebuthiuron at $1.1 \mathrm{~kg} \mathrm{ha}^{-1}$ (20P). A similar effect was evident for mountain big sagebrush and threetip sagebrush sites, but the patches were smaller $(<30 \mathrm{~cm}$ diameter $)$.

Table 5. Production (kg ha-1 oven-dry weight) by plant group for threetip eagebrush tebuthiuron treatment site at the U.S. Sheep Experiment Station.

\begin{tabular}{|c|c|c|c|c|c|c|}
\hline \multirow[b]{2}{*}{ Plant Group } & \multirow[b]{2}{*}{ Year } & \multicolumn{5}{|c|}{ Tebuthiuron Application Rate and Formulation ( $\mathrm{kg} \mathrm{ha}^{-1}$ active ingredient and percent) } \\
\hline & & Untreated & $0.6(20 \mathrm{P})$ & $0.6(40 P)$ & $1.1(20 \mathrm{P})$ & $1.1(40 \mathrm{P})$ \\
\hline Threetip sagebrush & $\begin{array}{l}1981 \\
1982 \\
1983\end{array}$ & $\begin{array}{l}364^{a_{1}} \\
167^{a} \\
218^{\star}\end{array}$ & $\begin{array}{c}59^{b c} \\
295^{a} \\
22^{b}\end{array}$ & $\begin{array}{r}122^{\mathrm{b}} \\
58^{\mathrm{b}} \\
177^{\mathrm{a}}\end{array}$ & $\begin{array}{l}21^{\mathrm{c}} \\
31^{\mathrm{b}} \\
11^{\mathrm{b}}\end{array}$ & $\begin{array}{c}112^{\mathrm{bc}} \\
56^{\mathrm{b}} \\
54^{\mathrm{b}}\end{array}$ \\
\hline Shrubs & $\begin{array}{l}1981 \\
1982 \\
1983\end{array}$ & $\begin{array}{l}412^{\star} \\
537^{\star} \\
317^{a}\end{array}$ & $\begin{array}{r}83^{b} \\
369^{b} \\
217^{b}\end{array}$ & $\begin{array}{l}207^{c} \\
134^{b} \\
201^{b}\end{array}$ & $\begin{array}{l}36^{\mathrm{c}} \\
60^{\mathrm{b}} \\
62^{\mathrm{c}}\end{array}$ & $\begin{array}{l}144^{\mathrm{bc}} \\
215^{\mathrm{b}} \\
131^{\mathrm{b}}\end{array}$ \\
\hline Grasses & $\begin{array}{l}1981 \\
1982 \\
1983\end{array}$ & $\begin{array}{l}454^{a} \\
237^{a} \\
486^{a}\end{array}$ & $\begin{array}{l}573^{\star} \\
505^{\star} \\
726^{\star}\end{array}$ & $\begin{array}{l}542^{a} \\
568^{a b} \\
578^{\star}\end{array}$ & $\begin{array}{l}269^{a} \\
452^{a} \\
454^{a}\end{array}$ & $\begin{array}{l}561^{a} \\
871^{b} \\
684^{a}\end{array}$ \\
\hline Forbs & $\begin{array}{l}1981 \\
1982 \\
1983\end{array}$ & $\begin{array}{r}65^{\circ} \\
63^{\circ} \\
106^{a}\end{array}$ & $\begin{array}{r}87^{\circ} \\
101^{\circ} \\
103^{2}\end{array}$ & $\begin{array}{r}98^{\star} \\
319^{\star} \\
258^{\star}\end{array}$ & $\begin{array}{r}47^{\star} \\
59^{\star} \\
138^{\star}\end{array}$ & $\begin{array}{r}62^{a} \\
123^{a} \\
152^{a}\end{array}$ \\
\hline
\end{tabular}

'Values not followed by the same letter in the same row are aignificantly different at $P \leq 0.5$.

Table 6. Live ahrub canopy cover percentage (mean and \pm standard error) before (1979) and one year after (1980) tebuthiuron application at the gray homebrush alte on the U.S. Sheep Experiment Station.

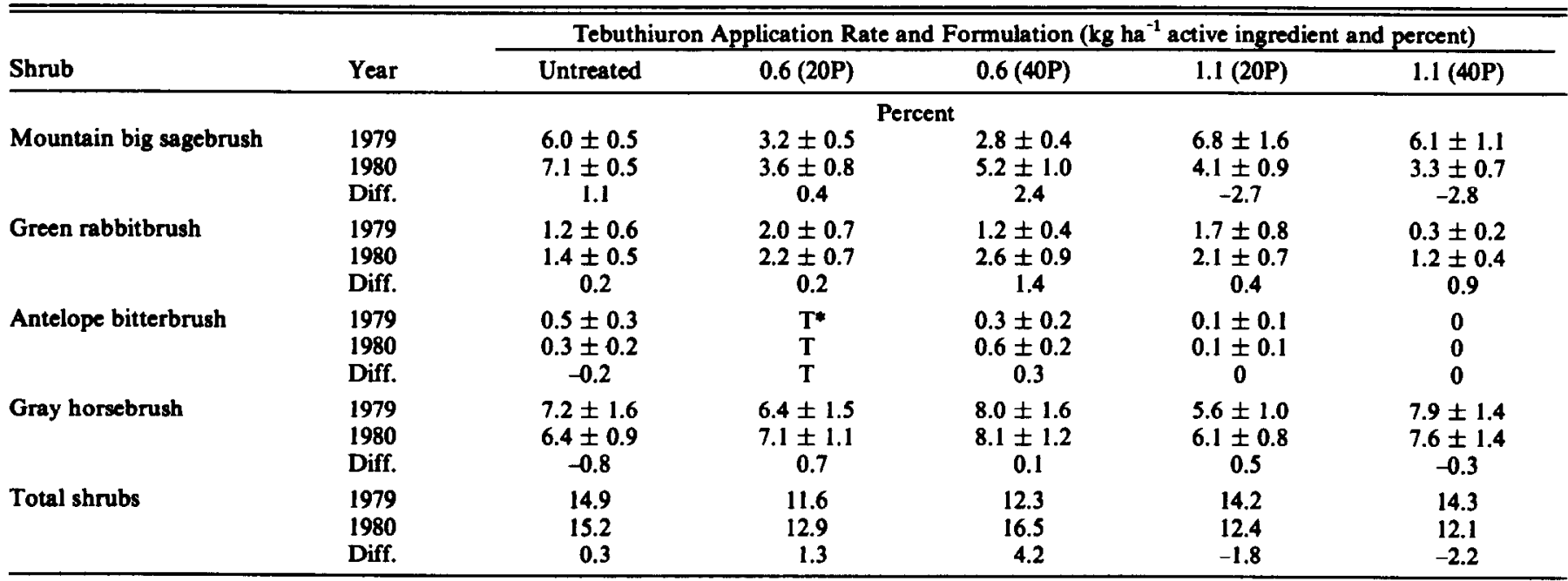

-Trace less than or equal to $0.05 \%$. 
Observations indicated no detectable differences in amounts of understory vegetation between treated and untreated plots during 1979 and 1980 , but by 1981 differences between certain treatments were evident.

\section{Mountain Biz Sagebrush Site}

Herbicide applications reduced the total shrub live crown cover 47 to $83 \%$ in the second growing season following treatment (Table 1). Mountain big sagebrush, the predominant species, accounted for most of the reduction. The $1.1 \mathrm{~kg} \mathrm{ha}^{-1}$ (20P) treatment resulted in the greatest reduction. The results reported here are similar to that found by Clary et al. (1985) in Utah for the $1.0 \mathrm{~kg} \mathrm{ha}^{-1}$ rate, but are lower than for the $0.6 \mathrm{~kg} \mathrm{ha}^{-1}$ rate. The heavier texture of our soil may have tied up a greater proportion of the herbicide especially at the lower rate. Another possibility is that the difference in response between studies at the $0.6 \mathrm{~kg} \mathrm{ha}^{-1}$ rate could be related to the difference in formulations used (10 vs. $20 \%$ ) as well as textural differences. At a given rate one would expect that twice as many pellets would be distributed at the $10 \%$ formulation compared to the $20 \%$ formulation resulting in a greater chance for the herbicide to intercept a live root. However, at the higher rate nearly all sagebrush plants might be affected at the formulation used.

The generally low cover of green rabbitbrush $(<0.05 \%$ and not shown), antelope bitterbrush, and gray horsebrush at this site led to erratic and nonsignificant data following most herbicide application (Table 1). Reduction in cover in 1980 suggests these species are susceptible to tebuthiuron as found by Britton and Sneva (1981) and Clary et al. (1985).

In the sixth growing season (1984) following herbicide application, the effects of different rates and formulations of tebuthiuron on shrubs were still evident (Table 2). Densities of mountain big sagebrush plants were $25,11,34$, and $35 \%$ of the untreated for the $0.6 \mathrm{~kg} \mathrm{ha}^{-1}(20 \mathrm{P}), 1.1 \mathrm{~kg} \mathrm{ha}^{-1}(20 \mathrm{P}), 0.6 \mathrm{~kg} \mathrm{ha}^{-1}(40 \mathrm{P})$, and $1.1 \mathrm{~kg}$ $\mathrm{ha}^{-1}(40 \mathrm{P})$ treatments, respectively. Like live shrub cover, the density of plants for other shrubs were erratic and not clearly related to treatment.

Production of current growth of mountain big sagebrush was reduced significantly $(P \leq .05)$ from the untreated shrubs at all rate-formulation combinations in all years (Table 3). Production differences between the herbicide treatments were nonsignificant.

During the first 2 growing seasons (1979-1980) following tebuthiuron application, observed and estimated production of grasses and forbs did not appear to be either increased or decreased from the untreated area. Although, by the end of the second growing season, small distinct patches nearly denuded of live vegetation occurred in the $1.1 \mathrm{~kg} \mathrm{ha}^{-1}(20 \mathrm{P})$ plots. In 1981 , total grass production was significantly $(P \leq .05)$ greater for the $1.1 \mathrm{~kg} \mathrm{ha}^{-1}(40 \mathrm{P})$ treatment area (Table 3).

Production in 1982 was approximately one-half that of 1981 and as a result treatment effects were not pronounced. By 1983 grass production was significantly greater than the untreated for all treatments except the $0.6 \mathrm{~kg} \mathrm{ha}^{-1}(40 \mathrm{P})$ formulation. When total grass production is considered over the 3 years, only the $1.1 \mathrm{~kg}$ (40P) formulation treatment was significantly greater than the untreated.

Table 7. Production (kg ha-1 oven-dry weight) by plant group for Gray Horsebrush tebuthiuron treatment site at the U.S. Sheep Experiment Station.

\begin{tabular}{|c|c|c|c|c|c|c|}
\hline \multirow[b]{2}{*}{ Plant Group } & \multirow[b]{2}{*}{ Year } & \multicolumn{5}{|c|}{ Tebuthiuron Application Rate and Formulation ( $\mathrm{kg} \mathrm{ha}^{-1}$ active ingredient and percent) } \\
\hline & & Untreated & $0.6(20 P)$ & $0.6(40 \mathrm{P})$ & $1.1(20 \mathrm{P})$ & $1.1(40 \mathrm{P})$ \\
\hline Gray horsebrush & $\begin{array}{l}1981 \\
1982\end{array}$ & $\begin{array}{r}94^{a_{1}} \\
114^{a}\end{array}$ & $\begin{array}{r}74^{n} \\
110^{n}\end{array}$ & $\begin{array}{l}39^{\circ} \\
81^{\circ}\end{array}$ & $\begin{array}{l}90^{\mathrm{a}} \\
35^{\mathrm{a}}\end{array}$ & $\begin{array}{r}100^{\mathrm{a}} \\
57^{\mathrm{a}}\end{array}$ \\
\hline Shrubs & $\begin{array}{l}1981 \\
1982\end{array}$ & $\begin{array}{l}280^{a} \\
638^{a}\end{array}$ & $\begin{array}{l}173^{\mathrm{ab}} \\
239^{\mathrm{b}}\end{array}$ & $\begin{array}{l}112^{\mathrm{b}} \\
287^{\mathrm{b}}\end{array}$ & $\begin{array}{c}143^{\mathrm{ab}} \\
90^{\mathrm{c}}\end{array}$ & $\begin{array}{c}200^{\mathrm{ab}} \\
195^{\mathrm{b}}\end{array}$ \\
\hline Grasses & $\begin{array}{l}1981 \\
1982\end{array}$ & $\begin{array}{l}410^{a} \\
149^{a}\end{array}$ & $\begin{array}{l}386^{a} \\
150^{a}\end{array}$ & $\begin{array}{l}430^{a} \\
237^{a}\end{array}$ & $\begin{array}{l}547^{a} \\
279^{n}\end{array}$ & $\begin{array}{l}317^{a} \\
232^{n}\end{array}$ \\
\hline Forbs & $\begin{array}{l}1981 \\
1982\end{array}$ & $\begin{array}{l}205^{a b} \\
155^{a}\end{array}$ & $\begin{array}{l}308^{\circ} \\
185^{n}\end{array}$ & $\begin{array}{l}260^{\mathrm{ab}} \\
205^{a}\end{array}$ & $\begin{array}{l}100^{\mathrm{b}} \\
120^{\mathrm{a}}\end{array}$ & $\begin{array}{l}150^{\mathrm{ab}} \\
186^{\mathrm{a}}\end{array}$ \\
\hline
\end{tabular}

Ivalues not followed by the same letter in the same row are significantly different at $P \leq .05$.
Among the individual grass species thickspike wheatgrass, bluebunch wheatgrass, and needle-and-thread grass responded to herbicide applications. Thickspike wheatgrass increased significantly due to the $1.1 \mathrm{~kg} \mathrm{ha}^{-1}(20 \mathrm{P})$ and to the $0.6 \mathrm{~kg} \mathrm{ha}^{-1}(40 \mathrm{P})$ rate formulation, while both bluebunch wheatgrass and needle-andthread grass increased significantly due to the $1.1 \mathrm{~kg} \mathrm{ha}^{-1}$ (40P) treatment (data not shown). Clary et al. (1985) found bluebunch wheatgrass increased significantly the first year following tebuthiuron application at the $1.3 \mathrm{~kg} \mathrm{ha}^{-1}$ (10P) treatment, but Clary admits this may not have had real meaning (personal communication). Bluebunch wheatgrass did decrease in subsequent years (Clary et al. 1985). Needle-and-thread grass live crown cover did not change for 2 years following tebuthiuron applications up to 1.1 $\mathrm{kg} \mathrm{ha}^{-1}$ at either the 10 or $20 \%$ formulations in Wyoming (Whitson and Alley 1984).

Western wheatgrass increased due to herbicide treatments applied at heavier rates and lower percentage formulations (Whitson and Alley 1984) like thickspike wheatgrass in this study. Western wheatgrass and thickspike wheatgrass are both strongly rhizomatous, and this characteristic may be responsible for its ability to endure heavier rates. Based on frequency measurements Britton and Sneva (1981) found all grass species decreased, except Idaho fescue (Festuca idahoensis Elmer), at tebuthiuron rates of 2 and 4 $\mathrm{kg} \mathrm{ha}^{-1}$ at the $20 \%$ formulation.

Forb production was unaffected by tebuthiuron applied at the rates and formulations used in this study. On a Utah juniper treatment area in Utah, Clary et al. (1985) found forb production declined at rates between 1.3 to $2.7 \mathrm{~kg} \mathrm{ha}^{-1}$ at the $10 \%$ formulation compared to the untreated, but found no differences from the untreated on the mountain big sagebrush site at rates between 0.6 and $1.3 \mathrm{~kg} \mathrm{ha}^{-1}$. The lack of forbs on the mountain big sagebrush site could account for this result.

Combined grass and forb production was significantly greater $(P \leq .05)$ on plots treated at the $1.1 \mathrm{~kg} \mathrm{ha}^{-1}(40 \mathrm{P})$ compared to the untreated or other herbicide treated plots. In the 3 years this treatment produced $52 \%\left(990 \mathrm{~kg} \mathrm{ha}^{-1}\right)$ more forage than the untreated.

\section{Threetip Sagebrush Site}

Reductions in total live shrub cover varied from 50 to $70 \%$ in the second growing season (1980) following herbicide application (Table 4). Threetip sagebrush was the most prevalent shrub and accounted for most of the reduction. As with mountain big sagebrush, threetip sagebrush live crown cover was reduced most by the $1.1 \mathrm{~kg} \mathrm{ha}^{-1}$ (20P) treatment (77\% reduction from untreated).

Live crown cover of other shrubs was low and responses to tebuthiuron treatments were more erratic than found at the mountain big sagebrush area. Part of this erratic response can be attributed to the differential amounts of surface rock between plots at this site. Plots with greater amounts of surface rock could either concentrate tebuthiuron in the interspaces or on the rock surfaces. As a result effective rates would be increased or decreased depending on the situation.

In 1984 density of threetip sagebrush plants $66,41,85$, and $72 \%$ 
of the untreated by the $0.6 \mathrm{~kg} \mathrm{ha}^{-1}(20 \mathrm{P}), 0.6 \mathrm{~kg} \mathrm{ha}^{-1}$ (40P), $1.1 \mathrm{~kg}$ $\mathrm{ha}^{-1}$ (20P), and $1.1 \mathrm{~kg} \mathrm{ha}^{-1}$ (40P) treatments, respectively (Table 2).

Total current production of threetip sagebrush was significantly reduced $(P \leq .05)$ by tebuthiuron application in 1981 (Table 5). Production was also reduced in 1982 and 1983 except for the $0.6 \mathrm{~kg}$ $\mathrm{ha}^{-1}(20 \mathrm{P})$ and $0.6 \mathrm{~kg} \mathrm{ha}^{-1}$ (40P) treatments. Variation in sampling appears to be the only explanation for these results.

Total grass production, resulting from tebuthiuron application, was not significantly different ( $P \leq .05$ from the untreated in 1981 and 1983 , but was significantly greater $(P \leq .05)$ for the $1.1 \mathrm{~kg} \mathrm{ha}^{-1}$ (40P) treatment in 1982 . Over the 3 years cheatgrass (Bromus tectorum L.) increased from an average of $17 \mathrm{~kg} \mathrm{ha}^{-1}$ in the untreated to $300 \mathrm{~kg} \mathrm{ha}^{-1}$ in the $1.1 \mathrm{~kg} \mathrm{ha}^{-1}$ (40P) treatment. Cheatgrass production also averaged $66 \mathrm{~kg} \mathrm{ha}^{-1}$ at the $0.6 \mathrm{~kg} \mathrm{ha}^{-1}$ rate compared to $200 \mathrm{~kg} \mathrm{ha}^{-1}$ at the $1.1 \mathrm{~kg} \mathrm{ha}^{-1}$ rate. Similarly, Clary et al. (1985) found a significant increase in cheatgrass in the tebuthiuron treated areas compared to untreated areas. Bluebunch wheatgrass increased significantly $(P \leq .05)$ due to the $0.6 \mathrm{~kg} \mathrm{ha}^{-1}(20 \mathrm{P})$ application. In the mountain big sagebrush site, bluebunch wheatgrass increased due to the $1.1 \mathrm{~kg} \mathrm{ha}^{-1}$ (40P) treatment. The reason for the difference between treatment responses is not clear. Sandberg's bluegrass declined an average of $44 \%$ from the untreated in the $1.1 \mathrm{~kg} \mathrm{ha}^{-1}$ (20P) treatment. Forb production was not significantly affected by any treatment in any years.

Total grass and forb production over the 3 years was $67 \%(952 \mathrm{~kg}$ $\left.\mathrm{ha}^{-1}\right)$ and $74 \%\left(1,042 \mathrm{~kg} \mathrm{ha}^{-1}\right)$ greater than the untreated on plots treated at $0.6 \mathrm{~kg} \mathrm{ha}^{-1}$ (40P) and $1.1 \mathrm{~kg} \mathrm{ha}^{-1}$ (40P), respectively. Significantly greater production $(P \leq .05)$ was associated with the $40 \%$ formulation in 1982 , but response to rates was similar.

\section{Gray Horsebrush Site}

Slight increase in total live crown cover occurred with the $0.6 \mathrm{~kg}$ $\mathrm{ha}^{-1}$ rate, and decreases with the $1.1 \mathrm{~kg} \mathrm{ha}^{-1}$ rate (Table 6). Total live shrub cover was considerably less at this site compared with other sites, but densities of plants were 43 and $23 \%$ greater than at the mountain big sagebrush and threetip sagebrush sites, respectively (Table 2). Six years after application total densities were reduced by all tebuthiuron treatments. The $1.1 \mathrm{~kg} \mathrm{ha}^{-1}(20 \mathrm{P})$ treatment reduced the density of shrubs by $64 \%$.

Production of gray horsebrush was not significantly affected $(P \leq .05)$ by any treatment during 1981 and 1982 (Table 7 ). Although in 1982 the production appeared to be reduced due to the $1.1 \mathrm{~kg} \mathrm{ha}^{-1}$ (20P) treatment, the trend probably did not continue because there were no reductions in density of horsebrush plants in 1984. However, when all shrubs are considered, significant reductions occurred compared to the untreated. Total grass and forb production were unaffected by any tebuthiuron treatment, and individual grasses and forbs did not respond to any treatment.

\section{Responses over All Sites}

Mountain big sagebrush was equally susceptible to all tebuthiuron treatments when production was averaged over all sites and years (Table 8). Threetip sagebrush and other shrubs were most susceptible to the $1.1 \mathrm{~kg} \mathrm{ha}^{-1}$ (20P) treatment. Standing crops of individual grasses varied in their responses to tebuthiuron. The 1.1 $\mathrm{kg} \mathrm{ha}^{-1}(20 \mathrm{P})$ rate formulation resulted in neither increases nor decreases in standing crops of grasses and sedges. Forb production increased significantly to the $0.6 \mathrm{~kg} \mathrm{ha}^{-1}(40 \mathrm{P})$ treatment, but did not respond to other treatments. When grass and forb production values are combined, the greatest increase occurred due to the 1.1 $\mathrm{kg} \mathrm{ha}^{-1}(40 \mathrm{P})$ treatment.

\section{Conclusions}

At the mountain big sagebrush and threetip sagebrush sites tebuthiuron applied at $1.1 \mathrm{~kg} \mathrm{ha}^{-1}(20 \mathrm{P})$ caused the greatest reduction in shrub live crown and cover and density of plants. However, this treatment also resulted in the poorest response of grasses. Using a $1.1 \mathrm{~kg} \mathrm{ha}^{-1}$ (40P) application should provide sufficient reduction of shrubs to enhance grass production.

Table 8. Live standing crops of species and species groups that were significantly $(P \leq .05)$ reduced or increased when considered over all sites and years. Values given are plus/minus the mean of the untreated plots. U.S. Sheep Experiment Station, Dubois, Idaho (1981-1983).

Species and Species Groups (Rates and Formulations) $\mathrm{kg} \mathrm{ha}^{-1}$ and percent

Artemisia tridentata vaseyana Artemisia tripartita

All shrubs

Bromus tectorum

Elymus lanceolatus

Stipa comata

All grasses and sedges

Cordylanthus ramosus

Polygonum douglassii

All forbs

Perennial forbs

Moderately desirable forbs

All grasses and forbs

Tebuthiuron, at the rates and formulations used in this study, caused little effect on shrubs at the gray horsebrush site in the first few years of the experiment. In the sixth growing season shrub densities were reduced significantly. Grass and forb production was not increased due to any treatment. At the time of production measurements (1981-1982), the plots contained many small shrubs which did not appear to have responded to the tebuthiuron treatments. It is not likely as the shrubs declined the grass and forb production would increase similar to that found at the mountain big sagebrush site, because the shrubs were smaller and probably did not use the soil moisture in the same pattern as the larger shrubs.

Shrub production at the mountain big sagebrush and threetip sagebrush sites was not significantly affected by the 40P formulation at both rates. Clearly sufficient herbicide was dispensed at the 40P formulation to interact with shrub roots, whereas more pellets reached individual grass plants at the 20P formulation than at the 40P formulation. Consequently any gain in grass production from sagebrush removal was offset by more plants being killed. No differences between rates or formulations for any plant groups were evident at the gray horsebrush site.

Within similar soil and environmental conditions this study shows that tebuthiuron applied at $1.1 \mathrm{~kg} \mathrm{ha}^{-1}$ rate and in a $40 \%$ formulation should result in significant increases in grass production when applied in the spring to mountain big sagebrush and threetip sagebrush ranges. Tebuthiuron applied at rates and formulations used in this experiment do not appear to be effective for increasing grass production on gray sagebrush sites.

\section{Literature Cited}

Bhaisdell, J.P., and W.F. Muezeler. 1956. Effect of 2,4-D on forbs and shrubs associated with big sagebrush. J. Range Manage. 9:38-40.

Barkworth, M.E., D.E. Dewey, and R.J. Atkins. 1983. New generic concepts in the Triticeae of the Intermountain Region: Key and comments. Great Basin Natur. 43:561-572.

Bovey, R.W., R.E. Meyer, and J.R. Baur. 1981. Potential herbicides for brush control. J. Range Manage. 34:144-148.

Britton, C.M., and F.A. Sneva. 1981. Effects of tebuthiuron on western juniper. J. Range Manage. 34:30-32.

Britton, C.M., and F.A. Sneva. 1983. Big sagebrush control with tebuthiuron. J. Range Manage. 36:707-708.

Clary, W.P., S. Goodrich, and B.M. Smith. 1985. Response of tebuthiuron by Utah juniper and mountain big sagebrush communities. J. Range Manage. 38:56-60.

Daubenmire, R.F. 1959. A canopy-coverage method of vegetational analysis. Northw. Sci. 33:43-64. 
Dewey, D.R. 1983. Historical and current taxonomic perspectives of Agropyron, Elymus, and related genera. Crop Sci. 23:637-642.

Dunnett, C.W. 1964. New tables for multiple comparisons with a control. Biometrics 20:482-491.

Hitcheok, C.L., A. Cronquist, M. Owenby, and J.W. Thompson. 1977. Vascular plants of the Pacific Northwest. V. 1-5. Univ. Washington Press, Seattle.

McDaniel, K.C., and J.F. Balliette. 1986. Control of big sagebrush (Artemisia tridentata) with pelleted tebuthiuron. Weed Sci. 34:276-280.

Pechanec, J.F., and G.D. Pickford. 1937. A weight estimate method for the determination of range or pasture production. J. Amer. Soc. Agron. 29:894-904.
Seifres, C.J. and J.L. Mutz. 1978. Herbaceous vegetation changes following applications of tebuthiuron for brush control. J. Range Manage. 31:375-378.

Seifrea, C.J., J.L. Mutz, and W.T. Hamilton. 1979. Control of mixed brush with tebuthiuron. J. Range Manage. 3:155-158.

Sosebee, R.E., W.E. Boyd, and G.S. Brumley. 1979. Broom snakeweed control with tebuthiuron. J. Range Manage. 32:179-182.

Whitson, T.D., and H.P. Alley. 1984. Tebuthiuron effects on Artemisia spp. and associated grasses. Weed Sci. 32:180-184. 